\title{
Descriptions of two New Genera and Species of reared Chalcididae from Borneo. (Hym.)
}

By P. Cameron, Whitle, New Mills (England).

Philopison gen. nov.

Antennae short, 8-jointed? if the terminal lobe be composed of 3 joints, the scape in $q$ slender, not much shorter than the following joints united, the pedicle longer than wide, the following 3 joints as wide as long, the end joint or joints swollen gradually, narrowed to a point; the scape in $\sigma^{7}$ greatly swollen and compressed, the base distinctly narrowed, the outerside of the dilated part thicker than the inner; it becomes gradually roundly widened towards the apex and is distinctly longer than the succeeding joints united; the antennae are placed over the mouth. Head narrow, very little developed behind, the temples obliquely narrowed. Eyes large, parallel; the ocelli in a curve. Pronotum large, narrowed gradually from the apex to the base, the sides roundly raised, the centre flat; the mesonotum raised in the centre, the base and apex obliquely sloped. Scutellum flat, the sides bordered by a broad, rounded keel. Abdomen sessile, wider than the thorax, flat, ovate, slightly shorter than the thorax. Legs normal, the femora moderately stout; the spurs slender, short; the tarsi slender, 5-jointed. Marginal vein a little shorter than postmarginal. The large eyes do not converge above with either sex.

The exact systematic position of the type of this genus is not quite clear to me, but for the present I should refer it to the Pireninae. Characteristic is the large, dilated antennal scape of the $\sigma^{7}$. The nature of the thoracic furrows and depressions may require revision, the specimens I have examined (all bred) appear not to have become quite hardened.

It is somewhat remarkable that there should be in Borneo two genera of Chalcididae belonging to different Tribes, with the antennal scape greatly enlarged in the males, this being a rare character with Chalcids.

\section{Philopison clavicornis sp. nov.}

Bronzy-black, the antennal scape and $1^{\text {st }}$ joint of flagellum and legs pale testaceous, the femora darker coloured - darker in some specimens than in others - the tarsi paler than the tibiae; wings clear hyaline, the nervures pale, almost white. Smooth, shining, bare. $q$ and $\sigma^{7}$. - Length $1 \mathrm{~mm}$. 
Kuching. Borneo. November. Bred by Mr. John Hewitt, from the cells of Pison sarawakensis, Cam. (Journ. St. Br. Roy. Asiat. Soc. No. 39, 1903, 163).

\section{Philolema gen. nov.}

$\sigma^{7}$. Antennae 9-jointed, the scape greatly swollen, 3 times longer than wide, curved, the $2^{\text {nd }}$ joint small, wider than long, the $3^{\text {rd }} 3$ times longer than wide, the $4^{\text {th }}$ to $8^{\text {th }}$ clearly separated, wider than long, the last conical, longer than wide; the scape in the $q$ not swollen nor curved, fully 4 times longer than wide, the other joints pretty much as in the $\sigma^{\top}$, but bare, those in the $\sigma^{7}$ having some short hairs; the antennae are placed close to the middle of the head. The inner side of the eyes is bordered by a stout keel, which extends below them and is separated from them by a weakly striated space. Eyes bare, prominent, as long as the malar space. Pronotum almost as long as the mesonotum, which has distinct curved parapsidal furrows. Scutellum large, prominent, rounded behind, longer than the mesonotum. Metanotum obliquely sloped, the centre being broadly raised and clearly separated from the sides, which are flatter. Abdomen shorter than the thorax; the $1^{\text {st }}, 3^{\text {rd }}$ and $4^{\text {th }}$ segments large, the $2^{\text {nd }}$ about half their length; the apical small, narrowed to a point. The post-costal nervure reaches beyond the middle of the wing, the stigma is not so long as the metacarpus; the radius is as long as the latter and is curved, thickened, but not cleft at the apex.

\section{Philolema carinigena sp. nov.}

Black, the antennal scape, apex of femora and the tibiae rufo-testaceous, the spurs and the tarsi almost white; wings hyaline, the nervures testaceous, the flagellum of antennae dark testaceous. $q$ and $\sigma^{7}$. - Length $3 \mathrm{~mm}$.

Kuching. Borneo. Bred by Mr. John Hewitt from cocoons of a species of Lema (Coleoptera).

Outer orbits and cheeks shagreened, irregularly reticulated, the latter more strongly than the orbits. There is a smooth, shining oval plate immediately below the antennae; this is bordered by keels which converge below; the sides of the face obliquely, somewhat strongly striated; the depressed centre of the front smooth, the sides closely rugosely punctured; the vertex and upper part of occiput closely umbilically punctured. Pro- and mesonotum and the scutellum coarsely umbilically punctured, the middle of metanotum obscurely transversely striated, the sides closely rugosely punctured. Pleurae finely rugosely punctured, 
more weakly on the middle of the mesopleurae above, where it is also more shining; the metapleurae and the coxae are densely covered with white pubescence. The tibiae are more densely covered with white hair than the rest of the legs.

\section{On some undescribed Vespidae from Borneo. (Hym.)}

By P. Cameron, Whitle, New Mills (England).

Odynerus Brooksii sp. nov.

Black, the clypeus, a small transverse oval spot over the antennae, the underside of the mandibles to near the apex, the eye incision, the mark prolonged downwards on the lower half, a short line behind the top of the head, a line on the pronotum, not reaching to the middle, scutellum except on the basal and apical slopes, 2 spots on postscutellum, a large irregular oval spot on the sides of metanotum, a large conical or oval mark (narrowest below) under the tegulae, a short oblique line below its apex, a line on the apex of the $1^{\text {st }}$ abdominal segment, a broader one on the apex of the $2^{\text {nd }}$, the apices of the $3^{\text {rd }}$ to $5^{\text {th }}$ in the middle, a large oblique oval mark on the sides of the $2^{\text {nd }}$ at the base, and the apex of the $2^{\text {nd }}$ ventral, yellow. Legs black, almost the apical half of the 4 fore femora, the fore tibiae except broadly behind at the base, the middle tibiae except behind, the posterior behind except at the apex, yellow; the tarsi for the greater part black. Underside of antennal scape yellow. Wings almost hyaline, the radial cellule fuscous violaceous, the nervures and stigma black; tegulae yellow, with a somewhat semicircular spot near the centre. $\sigma^{7}$. - Total length $8 \mathrm{~mm}$.

Kuching. August. (J o hn H ewitt.)

Clypeus longer than wide, strongly punctured, the apex bidentate, the teeth triangular. Base of thorax transverse, the sides of the apex broadly rounded. Scutellum broadly furrowed down the middle, the post-scutellum with a narrower furrow, its apex striated, broadly, bluntly rounded. Apex of metanotum stoutly, obliquely striated. The puncturation on the head is strong and close. The $1^{\text {st }}$ abdominal segment is longish cupshaped, strongly, closely punctured, the apex roundly raised, smooth; the $2^{\text {nd }}$ less strongly punctured, clearly longer than it is wide at the apex. Antennal hook, minute, sharp-pointed, black. The mandibular teeth are more distinct than usual; there 


\section{$2 \mathrm{BHL}$ Biodiversity Heritage Library}

Cameron, Peter. 1908. "Descriptions of two New Genera and Species of rearedChalcididae from Borneo. (Hym.)." Deutsche entomologische Zeitschrift 1908(5), 559-561. https://doi.org/10.1002/mmnd.48019080503.

View This Item Online: https://www.biodiversitylibrary.org/item/105322

DOI: https://doi.org/10.1002/mmnd.48019080503

Permalink: https://www.biodiversitylibrary.org/partpdf/235902

\section{Holding Institution}

Harvard University, Museum of Comparative Zoology, Ernst Mayr Library

\section{Sponsored by}

Harvard University, Museum of Comparative Zoology, Ernst Mayr Library

\section{Copyright \& Reuse}

Copyright Status: Public domain. The BHL considers that this work is no longer under copyright protection.

This document was created from content at the Biodiversity Heritage Library, the world's largest open access digital library for biodiversity literature and archives. Visit BHL at https://www.biodiversitylibrary.org. 